Article

\title{
Benzoic Acid Combined with Essential Oils Can Be an Alternative to the Use of Antibiotic Growth Promoters for Piglets Challenged with E. coli F4
}

\author{
Leticia Mendonça Rodrigues ${ }^{1}$, Túlio Otávio de Araújo Lima Neto ${ }^{1}$, \\ Cesar Augusto Pospissil Garbossa ${ }^{2}(0)$, Claudia Cassimira da Silva Martins ${ }^{3}$, Dino Garcez ${ }^{3}$, \\ Laya Kannan Silva Alves ${ }^{2} \mathbb{0}$, Márvio Lobão Teixeira de Abreu ${ }^{1}$, Rony Antonio Ferreira ${ }^{1}$ \\ and Vinícius de Souza Cantarelli ${ }^{1, *}$ \\ 1 Department of Animal Science, Federal University of Lavras, Lavras 37200-000, Brazil; \\ leticiamendoncarodrigues@gmail.com (L.M.R.); tulio.neto16@hotmail.com (T.O.d.A.L.N.); \\ marvio@ufla.br (M.L.T.d.A.); rony@ufla.br (R.A.F.) \\ 2 Department of Animal Nutrition and Production, School of Veterinary Medicine and Animal Science, \\ University of São Paulo, Pirassununga 13635-900, Brazil; cgarbossa@usp.br (C.A.P.G.); \\ layakannan@usp.br (L.K.S.A.) \\ 3 DSM Nutritional Products, São Paulo 01452-001, Brazil; claudia.silva@dsm.com (C.C.d.S.M.); \\ dino.garcez@hotmail.com (D.G.) \\ * Correspondence: vinicius@dzo.ufla.br; Tel.: +55-35-3829-1502
}

Received: 18 August 2020; Accepted: 16 October 2020; Published: 28 October 2020

Simple Summary: The use of antibiotics as growth promoters for swine must be minimized as it can promote resistance in microorganisms. Therefore, it is essential to search for alternative additives. This study aimed to investigate the effects of benzoic acid and a blend of essential oils (thymol, 2-methoxyphenol, eugenol, piperine, and curcumin) on the performance and intestinal health of weanling piglets challenged with Escherichia coli F4. The combination of benzoic acid and essential oils at $3 \mathrm{~g} / \mathrm{kg}$ improved the piglets' average daily gain and consequently their final body weight and it is an economically viable alternative to replace colistin. These results could have a great impact on society, contributing to the one heath concept and demonstrating the ability to replace antibiotics as growth promoters and thus minimize the chance of causing bacteria resistance.

\begin{abstract}
Benzoic acid (BA) and essential oils (EOs) (thymol, 2-methoxyphenol, eugenol, piperine, and curcumin) are being studied to minimize the impairment of gastrointestinal functions in weanling piglets. This study evaluates the effects of combining BA and EO on the performance and intestinal health of piglets challenged with E. coli $\mathrm{F} 4\left(1 \mathrm{~mL}, 10^{6} \mathrm{CFU} / \mathrm{mL}\right)$. In total, 270 weaned piglets were used in a randomized block design with six treatments: positive control, with $40 \mathrm{mg} / \mathrm{kg}$ colistin (PC); negative control, without the growth promoter (NC); negative control $+5 \mathrm{~g} / \mathrm{kg}$ benzoic acid (BA); negative control $+2 \mathrm{~g} / \mathrm{kg}$ combination of $\mathrm{BA}+\mathrm{EO}(\mathrm{BA}+\mathrm{EO} 2)$; negative control $+3 \mathrm{~g} / \mathrm{kg}$ combination of $\mathrm{BA}+\mathrm{EO}(\mathrm{BA}+\mathrm{EO} 3)$; negative control $+4 \mathrm{~g} / \mathrm{kg}$ combination of $\mathrm{BA}+\mathrm{EO}(\mathrm{BA}+\mathrm{EO} 4)$. $\mathrm{BA}+\mathrm{EO} 3$ presented a greater average daily gain (ADG) $(p=0.0013)$ and better feed-to-gain ratio $(p=0.0138)$, compared to $\mathrm{NC}$, from 21 to 35 days age. For the total period, $\mathrm{BA}, \mathrm{BA}+\mathrm{EO} 3$, and $\mathrm{BA}+\mathrm{EO} 4$ were similar to $\mathrm{PC}$ and superior to NC for ADG $(p=0.0002)$ and final body weight $(\mathrm{BW})(p=0.0002)$. No difference $(p>0.05)$ was verified for diarrhea, microbial population, production of volatile fatty acids, $\mathrm{pH}$, weight of organs, cellular proliferation, and cholecystokinin count. NC and BA+EO4 resulted in a higher villus height in the jejunum $(p=0.0120)$ compared to $\mathrm{BA}+\mathrm{EO}$. The use of $\mathrm{BA}$ or the combination of $\mathrm{BA}$ and $\mathrm{EO}$ at $3 \mathrm{~g} / \mathrm{kg}$ provides improved performance, aside from being an economically viable alternative to replace colistin.
\end{abstract}


Keywords: bacteria; microbiology; organic acid; pig nutrition; stress physiology; weaning

\section{Introduction}

The gastrointestinal tract (GIT) is a complex environment, especially after weaning, when there is separation of the piglet from the sow and the rest of the litter, a change of facility, the imposition of a new social life, and an abrupt change from a liquid diet to one based on less digestible plants [1]. With the occurrence of these stressful events, there is a fall in feed intake in the first two nursery weeks and some physiological functions of the GIT are not remodeled quickly enough to keep up with the changes and to maintain the piglet's performance [2]. Villi atrophy, deterioration of barrier function, and electrolyte absorption and secretion disturbances are triggered [3], leading to an increased susceptibility to infectious agents and generating clinical signs such as diarrhea and reduced feed intake $[4,5]$.

The occurrence of diarrhea is a serious consequence, which can lead to morbidity and mortality in piglets. Most occurrences in this phase are caused by enterotoxigenic Escherichia coli, a highly proliferating pathogenic bacterial strain that has fimbriae for adhering to the intestinal mucosa and proliferating [6]. For many years, the administration of non-therapeutic concentrations of antimicrobial agents, known as growth-promoting antibiotics (GPAs), has been and remains the main line of defense in swine farming $[7,8]$.

Colistin has been a widely used antibiotic in agriculture since 1950, performing specific actions against Gram-negative bacteria (GNB) such as Enterobacter aerogenes, Escherichia coli, and species of Salmonella [9-11]. The mechanism involves passage through the lipopolysaccharide barrier of the outer membrane, followed by denaturation of the plasma membrane, extravasation of cellular constituents, and cell death $[9,12]$.

According to Kempf et al. [13], the overuse of colistin in both human and veterinary medicine has quickly caused the development of resistance in GNB to current antibiotics. Given the importance of this antibiotic, it has been reclassified onto the List of Critically Important Antimicrobials for Human Medicine by the World Health Organization [14].

The emergence of antibiotic-resistant bacterial strains has led to many important pork markets banning colistin as a growth promoter. Liu et al. [15] described bacterial resistance to colistin in animals and humans, highlighting the resistant plasmid among strains of Escherichia coli. To minimize its use on piglets and economic problems in this stage, as well as to seek alternatives to antibiotics, benzoic acid and essential oils have been used. Studies show that benzoic acid has an antibacterial action and positive impacts on the performance of weanling piglets, showing a $12 \%$ improvement in average daily gain (ADG) [16-19]. Microbiota modulation and improved performance (11\% greater ADG) have also been observed in poultry and pigs supplemented with essential oils [20-23].

Due to the lipophilic characteristic of essential oils and benzoic acid when not dissociated, both can diffuse through the bacterial cell wall, altering its permeability. The release of $\mathrm{H}^{+}$ions inside the cell makes the bacteria attempt to resume homeostasis, removing protons through the $\mathrm{Na}^{+} / \mathrm{K}^{+}$pump. An active process that promotes bacterial depletion diminishes its pathogenicity and compromises vital processes [21,24,25], characterizing a bactericidal or bacteriostatic effect. Thus, the association of benzoic acid and essential oils shows synergistic activity in which essential oil compounds can damage and make the pathogenic organisms' cell walls more permeable, allowing easier entry and dissociation of the acid inside the cell $[26,27]$.

This study aimed to investigate the effects of combining benzoic acid and a blend of essential oils, at different concentrations, compared to benzoic acid alone at a customary dose and to an antibiotic. Based on an evaluation of the treatment effects on the performance and intestinal health of weanling piglets challenged with Escherichia coli F4, the study strives to understand if the dose of benzoic acid can be reduced when associated with essential oils. 


\section{Materials and Methods}

\subsection{Animals and Feed}

The experiment was conducted in the Swine Experimental Center at the Animal Science Department of the Federal University of Lavras (UFLA, Lavras, Brazil), in Lavras, Minas Gerais, Brazil. The Ethics Committee on the Use of Animals (CEUA, Lavras, Brazil) at UFLA approved the experimental procedures under Protocol no. 067014.

Two hundred and seventy barrows were used (a cross between DanBred-DB90 females and PIC-AGPIC337 males), weaned at the age of 21 days with an initial body weight (BW) of $5.76 \pm 0.52 \mathrm{~kg}$. They were housed in suspended pens, with slatted floors, semiautomatic feeders, and nipple drinkers. The windows and heat lamps were used to keep the temperature of the barn close to the ideal temperature for piglets at the post-weaning age. In the first nursery week, the temperature was maintained around $26.6 \pm 1.7{ }^{\circ} \mathrm{C}$, decreasing weekly to $23.8 \pm 1.1^{\circ} \mathrm{C}$ in the last week of the trial. The relative humidity was $63 \%$ in the first week and $69 \%$ in the last week.

The feed was formulated to meet the nutritional requirements according to the NRC (2012), in three nursery phase periods: pre-initial 1 (21 to 31 days old), pre-initial 2 (32 to 48 days old), and initial (49 to 63 days old) (Table 1). The diets had the same composition, differing only in the participation or not of additives and an antibiotic. Levels of supplemented additives (benzoic acid-BA and essential oil-EO) were analytically verified in the trial diets as described below.

Table 1. Centesimal composition and calculated nutritional values of the diets used in the different phases of the experiment.

\begin{tabular}{|c|c|c|c|}
\hline Ingredients ( $\mathrm{g} / \mathrm{kg}$, as-Fed Basis) & Pre-Initial 1 & Pre-Initial 2 & Initial \\
\hline Corn & 245.00 & 395.00 & 615.00 \\
\hline Soybean meal $45 \%$ & 150.00 & 200.00 & 270.00 \\
\hline Micronized whole soybeans & 90.00 & 17.50 & 70.00 \\
\hline Soy protein concentrate & 60.00 & 62.50 & - \\
\hline Starch & 234.49 & 158.21 & 07.57 \\
\hline Whey powder & 120.97 & 62.50 & - \\
\hline Dairy product, $38 \%$ lactose $^{1}$ & 60.00 & 62.50 & - \\
\hline DL-methionine & 2.27 & 1.87 & 1.01 \\
\hline L-tryptophan & 0.52 & 0.40 & 0.08 \\
\hline L-threonine & 1.85 & 1.58 & 0.91 \\
\hline L-lysine & 5.00 & 4.34 & 3.12 \\
\hline L-valine & 1.14 & 0.71 & - \\
\hline Phytase & 0.10 & 0.10 & 0.10 \\
\hline Premix Vit/Min ${ }^{2}$ & 10.00 & 10.00 & 10.00 \\
\hline Salt & 2.00 & 2.50 & 4.00 \\
\hline Limestone & - & - & 5.79 \\
\hline Dicalcium phosphate & 5.42 & 7.04 & 6.68 \\
\hline Calcium sulfate & 5.50 & 7.50 & - \\
\hline Antioxidant $^{3}$ & 0.25 & 0.25 & 0.25 \\
\hline Flavoring 4 & 0.50 & 0.50 & 0.50 \\
\hline Caolin ${ }^{\circ}$ & 5.00 & 5.00 & 5.00 \\
\hline \multicolumn{4}{|c|}{ Calculated values $n$ (g/kg, unless specified) } \\
\hline Metabolizable energy, MJ/kg & 15.5 & 15.1 & 13.6 \\
\hline Crude protein & 214.8 & 190.8 & 204.4 \\
\hline Total lysine & 15.1 & 14.4 & 13.2 \\
\hline Digestible lysine & 14.5 & 13.9 & 11.7 \\
\hline $\mathrm{Ca}$ & 7.3 & 6.3 & 6.0 \\
\hline $\mathrm{P}$ & 5.2 & 4.7 & 4.5 \\
\hline Lactose & 107.5 & 67.5 & - \\
\hline
\end{tabular}

${ }^{1}$ Commercial product Nuklospray E50. ${ }^{2}$ Composition/kg of product: $12 \mathrm{mg} \mathrm{Cu}$ as $\mathrm{CuSO}_{4} ; 80 \mathrm{mg}$ Fe as $\mathrm{FeSO}_{4}$ ); $1 \mathrm{mg} \mathrm{I}$ as $\mathrm{Ca}\left(\mathrm{IO}_{3}\right)_{2} ; 40 \mathrm{mg} \mathrm{Mn}$ as $\mathrm{MnO}_{2} ; 36 \mathrm{mg} \mathrm{Se}$ as $\mathrm{NaSeO}_{3} ; 110 \mathrm{mg} \mathrm{Zn}$ as $\mathrm{ZnO}$; vit. A (6875.00 I.U.); vit. D3 (1505.00 I.U.); vit. E (40.00 mg); vit. K3 (3.07 mg); vit. B1 (1.00 mg); vit. B2 (3.13 mg); vit. B6 (2.00 mg); vit. B12 $(0.02 \mathrm{mg})$; niacin $(30.00 \mathrm{mg})$; folic acid $(0.30 \mathrm{mg})$; pantothenic acid $(15.00 \mathrm{mg})$; biotin $(0.10 \mathrm{mg})$; choline $(200.97 \mathrm{mg}) .{ }^{3}$ Commercial product Banox E. ${ }^{4}$ Commercial product Luctarom Lactantes. ${ }^{5}$ Inert matter composed of hydrated aluminum silicates. 
The extractable content of the additives was obtained by hot methanol extraction in a Soxhlet extraction system. The insoluble products remained in the cartridge, which was then dried and weighed. Thymol was extracted with acetone and analyzed with a gas chromatography system with a flame ionization detector. The assay was carried out with pure thymol as an external standard and p-Fluorovalerophenone as the internal standard. Benzoic acid was extracted with $50 \mathrm{mM}$ sodium hydroxide as a solvent and quantified by reversed-phase HPLC-UV (272 nm) with benzoic acid as an external standard.

\subsection{Experimental Design}

The experimental design was in randomized blocks and the piglets were distributed in six treatments, with nine repetitions of five piglets each. The treatments consisted of: positive control with $40 \mathrm{mg} / \mathrm{kg}$ colistin (PC); negative control without the use of the growth promoter (NC); negative control $+5 \mathrm{~g} / \mathrm{kg}$ benzoic acid (BA); negative control $+2 \mathrm{~g} / \mathrm{kg}$ of the combination of benzoic acid and essential oils, with $1.800 \mathrm{~g}$ BA and $0.072 \mathrm{~g}$ EO (BA+EO2); negative control $+3 \mathrm{~g} / \mathrm{kg}$ of the combination of benzoic acid and essential oils, with $2.700 \mathrm{~g}$ BA and $0.108 \mathrm{~g} \mathrm{EO}(\mathrm{BA}+\mathrm{EO} 3)$; negative control $+4 \mathrm{~g} / \mathrm{kg}$ of the combination of benzoic acid and essential oils, with $3.600 \mathrm{~g} \mathrm{BA}$ and $0.144 \mathrm{~g}$ EO (BA+EO4). All the additives were added in substitution of the inert material of the diets (caolin) during the feed manufacturing.

As a source of benzoic acid, VevoVitall ${ }^{\circledR}$ was used, with a $99 \%$ acid concentration. The commercial product VevoWin ${ }^{\circledR}$ was used for the combination of additives. It is composed of $90 \%$ benzoic acid and $3.6 \%$ of a blend of encapsulated essential oils. The blend of essential oils includes thymol, 2-methoxyphenol, and eugenol with an estimated total of $10 \%$, and piperine and curcumin with an estimated total of 3\%. DSM Produtos Nutricionais Brasil SA provided the products.

The evaluated compositions of benzoic acid and thymol for the diets were as follows: PC and NC did not present benzoic acid nor thymol, BA presented $4.96 \mathrm{~g}$ of benzoic acid per $\mathrm{kg}$ of diet and did not present thymol, BA+EO2 presented $1.61 \mathrm{~g}$ of benzoic acid and $2.806 \mathrm{mg}$ of thymol per $\mathrm{kg}$ of diet, BA+EO3 presented $2.42 \mathrm{~g}$ of benzoic acid and $4.221 \mathrm{mg}$ of thymol per $\mathrm{kg}$ of diet, and BA+EO4 presented $3.2 \mathrm{~g}$ of benzoic acid and $5.606 \mathrm{mg}$ of thymol per $\mathrm{kg}$ of diet.

\subsection{Experimental Procedures}

The experimental period lasted 42 days. On the first experimental day, the piglets received an intramuscular dose $(0.15 \mathrm{~mL})$ of tulathromycin antibiotic (Draxxin ${ }^{\circledR}$, Zoetis, Parsippany-Troy Hills, NJ, USA), for the control of respiratory diseases. According to Silveira [28], this antibiotic acts mainly in the lungs, which could minimize any other factor that is not associated with enteric challenges.

All the piglets were challenged with two doses of Escherichia coli $\mathrm{F} 4$ inoculum $\left(\mathrm{LT}^{+}, \mathrm{STa}^{+}\right.$, and STb $\left.{ }^{+}\right)$, at a concentration of $10^{6} \mathrm{CFU} / \mathrm{mL}$. This dose was established in a previous trial by our team [28]. They received the $1 \mathrm{~mL}$ dose orally on the seventh and eighth days of the experiment. The Swine Health Laboratory, at the School of Veterinary Medicine and Animal Science of University of São Paulo, isolated the Escherichia coli F4 (LSS-103/2008) and the Microbiology Laboratory in the UFLA Animal Science Department prepared the inoculum. The strain was grown in a culture medium for $16 \mathrm{~h}$ at $37^{\circ} \mathrm{C}$, and then washed in PBS, at a concentration of $10^{6} \mathrm{CFU} / \mathrm{mL}$.

Nine piglets, one from each experimental unit (with the nearest live weight to the mean of the pen), were euthanized fourteen days after inoculation, at 42 days old. The insensibilization method used for slaughter was electronarcosis and then the exsanguination was carried out. This procedure allowed for the determination of relative organ weight, cecal content for microbiological and volatile fatty acid analyses, $\mathrm{pH}$ values of the GIT, intestinal histomorphometry, cell proliferation, and cholecystokinin counts.

During the second experimental week, five pigs died, one from the NC treatment, two from the BA treatment, and two from the BA+OE4 treatment, all from different experimental units. In order to correct the feed consumption and feed conversion, the procedure suggested by Sakomura and 
Rostagno [29] was adopted, which consists of weighing all piglets in the experimental unit as well as the feed leftovers of each experimental unit on the day of death.

\subsection{Performance and Incidence of Diarrhea}

For the performance evaluation, the piglets were weighed at 21, 35, 42, 49 and 63 days old. Average daily gain (ADG), average daily feed intake (ADFI), and feed-to-gain ratio (F:G) were calculated.

Twice a day, a trained person performed the evaluation of fecal scores by stool classification in the pen. The absence of diarrhea was determined by observing normal feces and the presence of diarrhea was determined by observing liquid and pasty feces, similar to the methodology proposed by Xiao et al. [30]. The occurrence of diarrhea was calculated by the percentage of diarrhea-positive pens compared to the total observations in one period, finding the percentage for 21 to 35,21 to 42,21 to 49 , and 21 to 63 days old.

\subsection{Microbiology}

For the microbiological analysis, fecal samples were collected on the fourth day after inoculation and cecal content was sampled at slaughter, to compare the microbiological profile right when the challenge was established and after a period of possible recovery of the piglets. Population analyses were conducted via culture using the specific selective medium method. Ten-fold serial dilutions were made and $100 \mu \mathrm{L}$ of each $10^{-2}$ to $10^{-5}$ dilution was mixed with $900 \mu \mathrm{L} 0.9 \%$ saline seeded in plates with Rogosa medium (Sigma-Aldrich, St. Louis, MO, USA) for Lactobacillus spp., in BSM medium (Sigma-Aldrich, St. Louis, MO, USA) for Bifidobacterium, and in VRB medium (3M ${ }^{\mathrm{TM}}$ Petrifilm ${ }^{\mathrm{TM}}$, Sumaré, SP, Brazil) for Escherichia coli and total coliforms.

\section{6. pH of the Gastrointestinal Tract and Organ Weight}

After the slaughter, the $\mathrm{pH}$ of the content of each gastrointestinal tract segment was measured (stomach, duodenum, jejunum, ileum, and cecum) by cutting and inserting a $\mathrm{pH}$ meter probe (Testo 205 model-Testo do Brasil).

The pancreas, spleen, and liver of the euthanized piglets were also collected for evaluation of the relative weight of these organs. Equation (1) was used to determinate this.

$$
\text { Organ relative weight }=(\text { organ weight } \div \text { body weight }) \times 100
$$

\subsection{Volatile Fatty Acids}

Following the methodology described by Playne [31], the analysis of volatile fatty acids (acetic, propionic, and butyric) was conducted based on the cecal content collected after slaughter. Briefly, $1 \mathrm{~mL}$ of $25 \%$ metaphosphoric acid was mixed with $5 \mathrm{~mL}$ of cecal content sample in a $15 \mathrm{~mL}$ centrifuge tube and the mixture was frozen overnight. The samples were then thawed, neutralized with $0.4 \mathrm{~mL}$ of $25 \% \mathrm{NaOH}$, and vortexed. Afterwards, $0.64 \mathrm{~mL}$ of $0.3 \mathrm{M}$ oxalic acid was added to the samples and they were vortexed again. The samples were then centrifuged for $20 \mathrm{~min}$ at $3000 \times g$ at $4{ }^{\circ} \mathrm{C}$ and $2 \mathrm{~mL}$ supernatant was transferred into a gas chromatography vial for volatile fatty acids analysis. The injector and detector temperatures were, respectively, 250 and $300^{\circ} \mathrm{C}$. The furnace heating schedule started at $60^{\circ} \mathrm{C}$ for $1 \mathrm{~min}$, then increased to $200{ }^{\circ} \mathrm{C}$ at a heating rate of $5^{\circ} \mathrm{C} \mathrm{min}{ }^{-1}$ and remained $1 \mathrm{~min}$ at the final temperature. Helium gas was used as a carrier gas and make-up at a flow rate of 1 and $29 \mathrm{~mL} \mathrm{~min}-1$, respectively. The flame ionization detector was powered by air $\left(300 \mathrm{~mL} \mathrm{~min}^{-1}\right)$ and hydrogen $\left(30 \mathrm{~mL} \mathrm{~min}^{-1}\right)$. The chromatographic system was calibrated with standard solutions of the studied acids in the concentration range of $5-500 \mu \mathrm{g} \mathrm{mL}^{-1}$. The injection volume for standard solutions and samples was $1 \mu \mathrm{L}$. The standards used were of high purity $(>99 \%)$. The acetic acid standard was obtained from Sigma-Aldrich (St. Louis, MO, USA), the propionic acid standard ( $>99 \%)$ was obtained from Merck (Honenbrunn, Germany), and the butyric acid standard (>99\%) was obtained 
from Aldrich (Milwaukee, WI, USA). From these standards, working solutions containing the three acids were prepared, in different concentrations, by dilution in deionized water.

\subsection{Intestinal Morphology}

The duodenum, jejunum, ileum, and colon samples were collected, respectively, $10 \mathrm{~cm}$ after the pylorus, $2.0 \mathrm{~m}$ from the pylorus, $10 \mathrm{~cm}$ anterior to the cecal ileum junction, and $10 \mathrm{~cm}$ posterior to the cecum. They were previously washed with saline solution, fixed in Bouin solution for $12 \mathrm{~h}$, dehydrated, inserted into paraffin, cut into a microtome $(4 \mu \mathrm{m})$, and the slides were stained with hematoxylin and eosin, following the methodology proposed by Pluske et al. [32].

The duodenum, jejunum, and ileum slides were sampled with ten villi for the evaluation of villus height and with ten crypts for crypt depth, and for the colon ten crypts were sampled. They were analyzed using the OLYMPUS CX31 optical microscope with an OLYMPUS SC30 camera attached, and the Axio Vision Release 4.9 (ZEISS) analysis software was used.

\subsection{Cellular Proliferation}

New histological slides of the jejunum were prepared to evaluate cell proliferation through detection of proliferating cell nuclear antigen (PCNA), by immunohistochemistry [33]. After deparaffinization and rehydration of the slides, endogenous peroxidase activity was blocked using Peroxidase Block reagent (DakoCytomation, Fort Collins, CO, USA), and then the non-specific antibody bindings were blocked using Block Serum reagent (DakoCytomation, Fort Collins, CO, USA).

The histological sections were incubated with the anti-PCNA monoclonal antibody (PC 10Dako ${ }^{\circledR}$ A/S. Denmark) at a dilution of 1:1000 for $1 \mathrm{~h}$ at room temperature. Subsequently, they were incubated with the secondary polyclonal antibody (HRP Dako Envision ${ }^{\circledR}$ —code K401111) at a 1:1 dilution for $30 \mathrm{~min}$ at room temperature. For revelation, $50 \mu \mathrm{L}$ of diaminobenzidine (DAB) was used (Dako Envision ${ }^{\circledR}$, code K346811), and after immunostaining, the sections were counterstained with Carazzi hematoxylin.

Proliferation was expressed as the percentage of PCNA positive cells to total crypt cells. Five fields per sample were evaluated, nine samples per treatment, in representative areas using $400 \times$ magnification. The slides were analyzed using the OLYMPUS CX31 optical microscope with an OLYMPUS SC30 camera attached, and the Image ${ }^{\circledR} 1.41$ image analysis software was used.

\subsection{Cholecystokinin Count}

Histological duodenum slides were also prepared for the cholecystokinin count (CCK) count, by immunohistochemistry [34]. After deparaffinization and rehydration of the slides, endogenous peroxidase activity and non-specific antibody bindings were blocked as described previously.

The histological sections were incubated with primary polyclonal antibody CCK-8 (T 4254Península $\mathrm{Lab}^{\circledR}$ ) at 1:1000 dilution for $3 \mathrm{~h}$ at room temperature. Subsequently, they were incubated with the secondary polyclonal antibody (HRP Dako Envision ${ }^{\circledR}$ —code K401111) at a 1:1 dilution for $30 \mathrm{~min}$ at room temperature. For revelation, $50 \mu \mathrm{L}$ of diaminobenzidine (DAB) was used (Dako Envision ${ }^{\circledR}$, code K346811), and after immunostaining, the sections were counterstained with Carazzi hematoxylin. Positive structures for CCK in the crypts were quantified. The evaluation was carried out in the same way as described for PCNA, differing only in the magnification used here, which was 200x.

\subsection{Economic Analysis}

To evaluate the viability of using each additive, an economic analysis was performed at the end of the experiment, considering different production items.

The variables analyzed were net revenue (NR), considering gross revenue from sale of piglet upon leaving the nursery (GRSP), gross cost of feed (GCF) and other production costs (OPCs), according to data from the Poultry and Swine Intelligence Center (CIAS) for Santa Catarina-Brazil, in 2014. 
Other production costs were represented by cost of feed $(28.83 \%)$, transport expenses $(1.45 \%)$, finance charges $(0.18 \%)$, piglet purchase costs $(60.56 \%)$, sundry expenses $(1.82 \%)$, and remuneration on breeders and pigs in stock (7.17\%). Additionally, the return on investment (ROI) was analyzed, considering net gain obtained over the invested amount (gross cost of feed and other production costs). The cost per kilo of produced piglet (piglet cost $/ \mathrm{kg}$ ) was analyzed considering the costs in the nursery phase according to the pigs' BW at 63 days old.

\subsection{Statistical Analysis}

For the performance evaluation, incidence of diarrhea, and economic analysis, the experimental units were represented by five piglets until 42 days of age and represented by four piglets after 42 days of age. For the other evaluated parameters, one piglet per pen represented the experimental units.

The results were analyzed using the Statistical Analysis System computer program (SAS Inst. Inc., Cary, NC, USA). The Shapiro-Wilk test was used to analyze the normality of the data and when they did not present this distribution, transformation was performed using PROC RANK (SAS Inst. Inc.). All variables were subjected to analysis of variance. When there was a statistical difference according to the F Test $(p<0.05)$, the Tukey test was used to compare the means.

\section{Results}

\subsection{Performance}

In the period from 21 to 35 days old, the piglets that received a combination of benzoic acid and essential oils at $3 \mathrm{~g} / \mathrm{kg}$ (BA+EO3) presented a higher ADG and better F:G when compared to the piglets that received no additive (NC) $(p<0.05)$ (Table 2). In the period from 21 to 42 days old, the piglets in the $\mathrm{BA}+\mathrm{EO} 3$ groups and the group that received the antibiotic (PC) presented a higher ADG when compared to the negative control piglets.

Table 2. Effect of experimental diets on the performance of piglets challenged with E. coli F4.

\begin{tabular}{|c|c|c|c|c|c|c|c|c|}
\hline Variables & PC & NC & BA & $\mathrm{BA}+\mathrm{EO} 2$ & $\mathrm{BA}+\mathrm{EO} 3$ & $\mathrm{BA}+\mathrm{EO} 4$ & SEM & $p$-Value \\
\hline \multicolumn{9}{|c|}{21 to 35 days of age } \\
\hline BW & 5.77 & 5.76 & 5.77 & 5.76 & 5.76 & 5.76 & 0.001 & 0.135 \\
\hline ADFI & 0.22 & 0.20 & 0.22 & 0.21 & 0.23 & 0.21 & 0.010 & 0.232 \\
\hline ADG & $0.149^{a, b}$ & $0.112^{c}$ & $0.143^{a, b, c}$ & $0.126^{b, c}$ & $0.164^{\mathrm{a}}$ & $0.132^{\mathrm{a}, \mathrm{b}, \mathrm{c}}$ & 0.008 & 0.001 \\
\hline$F: G$ & $1.47^{\mathrm{a}, \mathrm{b}}$ & $1.86^{\mathrm{a}}$ & $1.57^{\mathrm{a}, \mathrm{b}}$ & $1.73^{\mathrm{a}, \mathrm{b}}$ & $1.42^{b}$ & $1.63^{a, b}$ & 0.089 & 0.014 \\
\hline \multicolumn{9}{|c|}{21 to 42 days of age } \\
\hline ADFI & 0.34 & 0.29 & 0.34 & 0.30 & 0.34 & 0.32 & 0.013 & 0.231 \\
\hline ADG & $0.22^{\mathrm{a}}$ & $0.17^{\mathrm{b}}$ & $0.20^{a, b}$ & $0.19^{\mathrm{a}, \mathrm{b}}$ & $0.23^{a}$ & $0.19^{a, b}$ & 0.010 & 0.003 \\
\hline$F: G$ & 1.57 & 1.79 & 1.56 & 1.59 & 1.50 & 1.73 & 0.077 & 0.092 \\
\hline \multicolumn{9}{|c|}{21 to 49 days of age } \\
\hline ADFI & $0.409^{a, b}$ & $0.355^{b}$ & $0.415^{\mathrm{a}}$ & $0.365^{\mathrm{a}, \mathrm{b}}$ & $0.414^{\mathrm{a}}$ & $0.407^{\mathrm{a}, \mathrm{b}}$ & 0.014 & 0.005 \\
\hline ADG & $0.27^{a, b}$ & $0.21^{\mathrm{c}}$ & $0.26^{\mathrm{a}, \mathrm{b}}$ & $0.22^{b, c}$ & $0.28^{\mathrm{a}}$ & $0.25^{\mathrm{a}, \mathrm{b}, \mathrm{c}}$ & 0.012 & 0.001 \\
\hline$F: G$ & 1.55 & 1.72 & 1.62 & 1.73 & 1.48 & 1.64 & 0.075 & 0.129 \\
\hline \multicolumn{9}{|c|}{21 to 63 days of age } \\
\hline ADFI & $0.63^{a, b}$ & $0.57^{\mathrm{b}}$ & $0.67^{\mathrm{a}}$ & $0.59^{b}$ & $0.63^{\mathrm{a}, \mathrm{b}}$ & $0.63^{a, b}$ & 0.016 & 0.002 \\
\hline ADG & $0.408^{\mathrm{a}, \mathrm{b}}$ & $0.357^{c}$ & $0.421^{\mathrm{a}}$ & $0.377^{b, c}$ & $0.419^{\mathrm{a}, \mathrm{b}}$ & $0.407^{\mathrm{a}, \mathrm{b}}$ & 0.010 & $<0.001$ \\
\hline$F: G$ & 1.54 & 1.61 & 1.58 & 1.56 & 1.51 & 1.56 & 0.028 & 0.200 \\
\hline BW & $22.96^{\mathrm{a}}$ & $20.78^{b}$ & $23.45^{\mathrm{a}}$ & $21.70^{\mathrm{a}, \mathrm{b}}$ & $23.38^{\mathrm{a}}$ & $22.98^{a}$ & 0.416 & $<0.001$ \\
\hline
\end{tabular}

$\mathrm{PC}$, positive control with $40 \mathrm{mg} / \mathrm{kg}$ colistin; $\mathrm{NC}$, negative control without the use of the growth promoter; $\mathrm{BA}$, negative control $+5 \mathrm{~g} / \mathrm{kg}$ benzoic acid; $\mathrm{BA}+\mathrm{EO} 2$, negative control $+2 \mathrm{~g} / \mathrm{kg}$ of the combination of benzoic acid and essential oils; $\mathrm{BA}+\mathrm{EO} 3$, negative control $+3 \mathrm{~g} / \mathrm{kg}$ of the combination of benzoic acid and essential oils; $\mathrm{BA}+\mathrm{EO} 4$, negative control $+4 \mathrm{~g} / \mathrm{kg}$ of the combination of benzoic acid and essential oils. BW, body weight $(\mathrm{kg})$; ADFI, average daily feed intake (kg/day); ADG, average daily gain $(\mathrm{kg} /$ day); F:G, feed-to-gain ratio $(\mathrm{kg} / \mathrm{kg})$; SEM, standard error of the mean. Means followed by different letters are significantly different according to the Tukey test $(p<0.05)$. 
In the period from 21 to 49 days old, the BA+EO3 piglets had a greater ADFI $(p<0.05)$ compared to the NC piglets, and a greater ADG $(p<0.05)$ compared to the NC and the BA+EO2 groups. The piglets of the BA+EO3 group had a similar ADFI $(p>0.05)$ and ADG $(p>0.05)$ to the BA, BA+EO4, as well as the PC piglets.

Considering the whole experimental period, the piglets that received only $5 \mathrm{~g} / \mathrm{kg}$ of benzoic acid (BA) presented a higher ADFI $(p<0.05)$ and ADG $(p<0.05)$ compared to NC and BA+EO2. A higher final BW $(p<0.05)$ was observed in this period for the piglets in the PC, BA, BA+EO3, and BA+EO4 groups compared to those in the NC group.

\subsection{Diarrhea Incidence}

No differences were observed $(p>0.05)$ for the incidence of diarrhea between treatments in the periods evaluated (Table 3).

Table 3. Effect of experimental diets on the incidence of diarrhea in piglets challenged with E. coli F4.

\begin{tabular}{|c|c|c|c|c|c|c|c|c|}
\hline Variables & PC & NC & BA & $\mathrm{BA}+\mathrm{EO} 2$ & $\mathrm{BA}+\mathrm{EO} 3$ & $\mathrm{BA}+\mathrm{EO} 4$ & SEM & $p$-Value \\
\hline \multicolumn{9}{|c|}{21 to 35 days of age } \\
\hline ID, \% & 24.1 & 37.5 & 34.6 & 27.4 & 29.3 & 29.0 & 4.893 & 0.432 \\
\hline \multicolumn{9}{|c|}{21 to 42 days of age } \\
\hline ID, \% & 21.9 & 31.1 & 28.6 & 27.9 & 26.8 & 22.3 & 3.313 & 0.267 \\
\hline \multicolumn{9}{|c|}{21 to 49 days of age } \\
\hline ID, $\%$ & 19.1 & 28.4 & 25.6 & 24.0 & 27.1 & 21.9 & 2.933 & 0.207 \\
\hline \multicolumn{9}{|c|}{21 to 63 days of age } \\
\hline ID, $\%$ & 13.3 & 19.4 & 17.5 & 17.3 & 15.8 & 16.0 & 2.175 & 0.316 \\
\hline
\end{tabular}

$\mathrm{PC}$, positive control with $40 \mathrm{mg} / \mathrm{kg}$ colistin; $\mathrm{NC}$, negative control without the use of the growth promoter; $\mathrm{BA}$, negative control $+5 \mathrm{~g} / \mathrm{kg}$ benzoic acid; $\mathrm{BA}+\mathrm{EO} 2$, negative control $+2 \mathrm{~g} / \mathrm{kg}$ of the combination of benzoic acid and essential oils; $\mathrm{BA}+\mathrm{EO} 3$, negative control $+3 \mathrm{~g} / \mathrm{kg}$ of the combination of benzoic acid and essential oils; $\mathrm{BA}+\mathrm{EO} 4$, negative control $+4 \mathrm{~g} / \mathrm{kg}$ of the combination of benzoic acid and essential oils. ID, incidence of diarrhea (\%); SEM, standard error of the mean.

\subsection{Microbiological Count}

The populations of Bifidobacterium, Lactobacillus spp., Escherichia coli, and total coliforms were also not affected by the experimental treatments $(p>0.05)$ in the pre-killing and post-killing periods (Table 4).

Table 4. Effect of experimental diets on the microbial concentration (CFU/g) in feces collected at 33 days of age (pre-killing) and on the cecal content collected at 42 days of age (post-killing) from piglets challenged with E. coli F4.

\begin{tabular}{|c|c|c|c|c|c|c|c|c|}
\hline Variables & PC & NC & BA & $\mathrm{BA}+\mathrm{EO} 2$ & $\mathrm{BA}+\mathrm{EO} 3$ & $\mathrm{BA}+\mathrm{EO} 4$ & SEM & $p$-Value \\
\hline \multicolumn{9}{|c|}{33 days of age (pre-killing) } \\
\hline Bifidobacterium & $3.3 \times 10^{8}$ & $1.4 \times 10^{8}$ & $2.4 \times 10^{8}$ & $1.4 \times 10^{8}$ & $3.2 \times 10^{8}$ & $1.7 \times 10^{8}$ & 1.140 & 0.273 \\
\hline Lactobacilli spp. & $3.7 \times 10^{8}$ & $2.1 \times 10^{8}$ & $2.5 \times 10^{8}$ & $2.0 \times 10^{8}$ & $2.7 \times 10^{8}$ & $1.4 \times 10^{8}$ & 0.579 & 0.253 \\
\hline Escherichia coli & $1.9 \times 10^{7}$ & $1.3 \times 10^{8}$ & $7.5 \times 10^{5}$ & $2.9 \times 10^{6}$ & $4.6 \times 10^{6}$ & $5.7 \times 10^{7}$ & 2.819 & 0.143 \\
\hline Total Coliforms & $1.9 \times 10^{7}$ & $1.6 \times 10^{8}$ & $1.3 \times 10^{6}$ & $3.1 \times 10^{6}$ & $4.3 \times 10^{6}$ & $5.7 \times 10^{7}$ & 1.854 & 0.245 \\
\hline \multicolumn{9}{|c|}{42 days of age (post-killing) } \\
\hline Bifidobacterium & $2.7 \times 10^{7}$ & $1.1 \times 10^{7}$ & $2.1 \times 10^{7}$ & $2.3 \times 10^{7}$ & $1.4 \times 10^{7}$ & $2.7 \times 10^{7}$ & 0.707 & 0.971 \\
\hline Lactobacilli spp. & $1.3 \times 10^{7}$ & $8.8 \times 10^{6}$ & $1.3 \times 10^{7}$ & $6.8 \times 10^{6}$ & $1.8 \times 10^{7}$ & $1.1 \times 10^{7}$ & 1.043 & 0.811 \\
\hline Escherichia coli & $2.0 \times 10^{5}$ & $2.1 \times 10^{6}$ & $5.2 \times 10^{5}$ & $1.5 \times 10^{9}$ & $1.2 \times 10^{6}$ & $1.2 \times 10^{6}$ & 3.128 & 0.523 \\
\hline Total Coliforms & $3.1 \times 10^{5}$ & $2.5 \times 10^{6}$ & $8.1 \times 10^{5}$ & $1.5 \times 10^{9}$ & $1.6 \times 10^{6}$ & $1.2 \times 10^{6}$ & 2.320 & 0.457 \\
\hline
\end{tabular}

PC, positive control with $40 \mathrm{mg} / \mathrm{kg}$ colistin; $\mathrm{NC}$, negative control without the use of the growth promoter; $\mathrm{BA}$, negative control $+5 \mathrm{~g} / \mathrm{kg}$ benzoic acid; $\mathrm{BA}+\mathrm{EO} 2$, negative control $+2 \mathrm{~g} / \mathrm{kg}$ of the combination of benzoic acid and essential oils; $\mathrm{BA}+\mathrm{EO} 3$, negative control $+3 \mathrm{~g} / \mathrm{kg}$ of the combination of benzoic acid and essential oils; $\mathrm{BA}+\mathrm{EO} 4$, negative control $+4 \mathrm{~g} / \mathrm{kg}$ of the combination of benzoic acid and essential oils. SEM, standard error of the mean. 


\section{4. $\mathrm{pH}$, Volatile Fatty Acids, and Relative Weight of Organs}

The results for $\mathrm{pH}$ (Table 5), production of volatile fatty acids (Table 6), and relative organ weight (Table 7) were not affected by the experimental treatments $(p>0.05)$. The experimental treatments also had no effect $(p>0.05)$ on the CCK count in the duodenum. The mean CCK number counted was $11.92 \pm 1.26$ units.

\subsection{Intestinal Histology}

For villus height, crypt depth, and the ratio between them, no treatment effect was observed $(p>0.05)$ in the duodenum and ileum segments (Table 8). Similarly, there was no significant difference $(p>0.05)$ for crypt depth in the colon. However, a reduction was noted $(p<0.05)$ for the villus height in the jejunum of the piglets in the BA+EO3 group compared to those in the NC and BA+EO4 groups. Stained and unstained PCNA cells in jejunum crypts were counted, but no treatment had a significant effect $(p>0.05)$. The mean cellular proliferation percentage was $46.46 \pm 6.29 \%$.

Table 5. Effect of experimental diets on the $\mathrm{pH}$ of piglets challenged with E. coli F4.

\begin{tabular}{lrccccccc}
\hline Variables & PC & NC & BA & BA+EO2 & BA+EO3 & BA+EO4 & SEM & $p$-Value \\
\hline Stomach & 3.7 & 3.1 & 3.5 & 3.4 & 3.2 & 3.7 & 0.780 & 0.518 \\
Duodenum5.7 & 5.7 & 5.7 & 5.3 & 5.3 & 5.5 & 0.745 & 0.724 \\
Jejunum & 5.9 & 6.2 & 6.0 & 5.9 & 6.1 & 5.9 & 0.429 & 0.757 \\
Ileum & 6.3 & 6.2 & 6.3 & 6.2 & 6.2 & 6.3 & 0.511 & 0.949 \\
Cecum & 5.7 & 5.7 & 5.7 & 5.6 & 5.6 & 5.6 & 0.231 & 0.642 \\
\hline
\end{tabular}

$\mathrm{PC}$, positive control with $40 \mathrm{mg} / \mathrm{kg}$ colistin; $\mathrm{NC}$, negative control without the use of the growth promoter; $\mathrm{BA}$, negative control $+5 \mathrm{~g} / \mathrm{kg}$ benzoic acid; $\mathrm{BA}+\mathrm{EO} 2$, negative control $+2 \mathrm{~g} / \mathrm{kg}$ of the combination of benzoic acid and essential oils; $\mathrm{BA}+\mathrm{EO} 3$, negative control $+3 \mathrm{~g} / \mathrm{kg}$ of the combination of benzoic acid and essential oils; $\mathrm{BA}+\mathrm{EO} 4$, negative control $+4 \mathrm{~g} / \mathrm{kg}$ of the combination of benzoic acid and essential oils. SEM, standard error of the mean.

Table 6. Effect of experimental diets on the production of volatile fatty acids ( $\mathrm{mMol} / \mathrm{g}$ ) in the cecum of piglets challenged with E. coli $\mathrm{F} 4$.

\begin{tabular}{|c|c|c|c|c|c|c|c|}
\hline Variables PC & NC & BA & $\mathrm{BA}+\mathrm{EO} 2$ & $\mathrm{BA}+\mathrm{EO} 3$ & $\mathrm{BA}+\mathrm{EO} 4$ & SEM & $p$-Value \\
\hline Acetic & 594.5 & 577.0 & 656.4 & 512.0 & 618.5 & 157.20 & 0.783 \\
\hline Propionic 337.8 & 363.8 & 297.7 & 329.2 & 300.4 & 298.7 & 93.27 & 0.649 \\
\hline Butyric 126.2 & 157.2 & 155.6 & 169.7 & 155.7 & 144.1 & 55.53 & 0.595 \\
\hline
\end{tabular}

$\mathrm{PC}$, positive control with $40 \mathrm{mg} / \mathrm{kg}$ colistin; NC, negative control without the use of the growth promoter; $\mathrm{BA}$, negative control $+5 \mathrm{~g} / \mathrm{kg}$ benzoic acid; $\mathrm{BA}+\mathrm{EO} 2$, negative control $+2 \mathrm{~g} / \mathrm{kg}$ of the combination of benzoic acid and essential oils; $\mathrm{BA}+\mathrm{EO} 3$, negative control $+3 \mathrm{~g} / \mathrm{kg}$ of the combination of benzoic acid and essential oils; $\mathrm{BA}+\mathrm{EO} 4$, negative control $+4 \mathrm{~g} / \mathrm{kg}$ of the combination of benzoic acid and essential oils. SEM, standard error of the mean.

Table 7. Effect of experimental diets on the relative weight of organs (\%) in piglets challenged with E. coli F4.

\begin{tabular}{lcccccccc}
\hline \multicolumn{1}{l}{ Variables } & PC & NC & BA & BA+EO2 & BA+EO3 & BA+EO4 & SEM & $p$-Value \\
\hline Pancreas & 0.24 & 0.24 & 0.22 & 0.24 & 0.23 & 0.21 & 0.031 & 0.419 \\
Spleen & 0.21 & 0.29 & 0.23 & 0.21 & 0.23 & 0.21 & 0.110 & 0.967 \\
Liver & 2.96 & 3.16 & 3.13 & 3.07 & 3.15 & 3.12 & 0.347 & 0.861 \\
\hline
\end{tabular}

$\mathrm{PC}$, positive control with $40 \mathrm{mg} / \mathrm{kg}$ colistin; $\mathrm{NC}$, negative control without the use of the growth promoter; $\mathrm{BA}$, negative control $+5 \mathrm{~g} / \mathrm{kg}$ benzoic acid; $\mathrm{BA}+\mathrm{EO} 2$, negative control $+2 \mathrm{~g} / \mathrm{kg}$ of the combination of benzoic acid and essential oils; $\mathrm{BA}+\mathrm{EO} 3$, negative control $+3 \mathrm{~g} / \mathrm{kg}$ of the combination of benzoic acid and essential oils; $\mathrm{BA}+\mathrm{EO} 4$, negative control $+4 \mathrm{~g} / \mathrm{kg}$ of the combination of benzoic acid and essential oils. SEM, standard error of the mean. 
Table 8. Effect of experimental diets on the intestinal morphology of piglets challenged with E. coli F4.

\begin{tabular}{|c|c|c|c|c|c|c|c|c|}
\hline Variables & PC & NC & BA & $\mathrm{BA}+\mathrm{EO} 2$ & $\mathrm{BA}+\mathrm{EO} 3$ & $\mathrm{BA}+\mathrm{EO} 4$ & SEM & $p$-Value \\
\hline \multicolumn{9}{|l|}{ Duodenum } \\
\hline VH & 265.3 & 282.7 & 285.0 & 262.6 & 292.4 & 293.8 & 32.12 & 0.108 \\
\hline $\mathrm{CD}$ & 203.2 & 210.8 & 212.6 & 201.0 & 199.3 & 208.4 & 26.99 & 0.842 \\
\hline VH:CD & 1.4 & 1.4 & 1.4 & 1.4 & 1.5 & 1.5 & 0.17 & 0.382 \\
\hline \multicolumn{9}{|l|}{ Jејипит } \\
\hline VH & $\begin{array}{c}233.1 \\
a, b\end{array}$ & $255.8^{a}$ & $\begin{array}{c}242.4 \\
\mathrm{a}, \mathrm{b}\end{array}$ & $\begin{array}{c}247.1 \\
\mathrm{a}, \mathrm{b}\end{array}$ & $220.1^{b}$ & $271.0^{\mathrm{a}}$ & 35.99 & 0.012 \\
\hline $\mathrm{CD}$ & 174.1 & 197.8 & 170.6 & 189.6 & 175.6 & 193.5 & 24.61 & 0.141 \\
\hline VH:CD & 1.4 & 1.3 & 1.5 & 1.3 & 1.3 & 1.5 & 0.21 & 0.412 \\
\hline \multicolumn{9}{|l|}{ Ileum } \\
\hline $\mathrm{VH}$ & 229.9 & 217.7 & 217.5 & 231.9 & 210.6 & 203.4 & 44.00 & 0.942 \\
\hline $\mathrm{CD}$ & 192.8 & 215.1 & 198.1 & 212.6 & 192.3 & 215.7 & 28.77 & 0.200 \\
\hline VH:CD & 1.3 & 1.1 & 1.2 & 1.1 & 1.1 & 1.0 & 0.28 & 0.585 \\
\hline \multicolumn{9}{|l|}{ Colon } \\
\hline $\mathrm{CD}$ & 351.2 & 312.0 & 334.9 & 364.4 & 330.6 & 321.4 & 53.67 & 0.417 \\
\hline
\end{tabular}

$\mathrm{PC}$, positive control with $40 \mathrm{mg} / \mathrm{kg}$ colistin; $\mathrm{NC}$, negative control without the use of the growth promoter; $\mathrm{BA}$, negative control $+5 \mathrm{~g} / \mathrm{kg}$ benzoic acid; $\mathrm{BA}+\mathrm{EO} 2$, negative control $+2 \mathrm{~g} / \mathrm{kg}$ of the combination of benzoic acid and essential oils; $\mathrm{BA}+\mathrm{EO} 3$, negative control $+3 \mathrm{~g} / \mathrm{kg}$ of the combination of benzoic acid and essential oils; $\mathrm{BA}+\mathrm{EO} 4$, negative control $+4 \mathrm{~g} / \mathrm{kg}$ of the combination of benzoic acid and essential oils. $\mathrm{VH}$, villus height $(\mu \mathrm{m})$; $\mathrm{CD}$, crypt depth $(\mu \mathrm{m}) ; \mathrm{VH}: \mathrm{CD}$, villus height/crypt depth ratio; $\mathrm{SEM}$, standard error of the mean. Means followed by different letters are significantly different according to the Turkey test $(p<0.05)$.

\subsection{Economic Evaluation}

The economic viability of using the treatments, considering production costs for a feeder pig operation, is shown in Table 9.

Table 9. Economic evaluation of using different experimental treatments.

\begin{tabular}{|c|c|c|c|c|c|c|c|c|}
\hline Variable & es PC & NC & BA & $\mathrm{BA}+\mathrm{EO} 2$ & $\mathrm{BA}+\mathrm{EO} 3$ & $\mathrm{BA}+\mathrm{EO} 4$ & SEM & $p$-Value \\
\hline GRSP & $45.5^{a, b}$ & $41.1^{\mathrm{b}}$ & $46.4^{\mathrm{a}}$ & $42.6^{a, b}$ & $46.5^{a}$ & $46.0^{a, b}$ & 3.688 & 0.005 \\
\hline GFC & 7.4 & 6.8 & 7.6 & 6.8 & 7.5 & 7.4 & 0.740 & 0.087 \\
\hline $\mathrm{OPC}$ & 18.1 & 18.1 & 18.1 & 18.1 & 18.1 & 18.1 & 0.000 & 1.000 \\
\hline NR & $20.0^{a, b}$ & $16.3^{b}$ & $20.7^{a}$ & $17.7^{\mathrm{a}, \mathrm{b}}$ & $21.0^{a}$ & $20.4^{\mathrm{a}}$ & 3.107 & 0.005 \\
\hline ROI & $78.3^{a, b}$ & $65.5^{b}$ & $80.6^{a}$ & $70.8^{\mathrm{a}, \mathrm{b}}$ & $81.8^{a}$ & $80.1^{a}$ & 3.357 & 0.006 \\
\hline $\begin{array}{l}\text { Piglet } \\
\text { cost } / \mathrm{kg}\end{array}$ & $1.11^{\mathrm{a}, \mathrm{b}}$ & $1.20^{\mathrm{a}}$ & $1.10^{\mathrm{b}}$ & $1.16^{\mathrm{a}, \mathrm{b}}$ & $1.09^{b}$ & $1.10^{b}$ & 0.022 & 0.005 \\
\hline
\end{tabular}

$\mathrm{PC}$, positive control with $40 \mathrm{mg} / \mathrm{kg}$ colistin; NC, negative control without the use of the growth promoter; $\mathrm{BA}$, negative control $+5 \mathrm{~g} / \mathrm{kg}$ benzoic acid; $\mathrm{BA}+\mathrm{EO} 2$, negative control $+2 \mathrm{~g} / \mathrm{kg}$ of the combination of benzoic acid and essential oils; $\mathrm{BA}+\mathrm{EO} 3$, negative control $+3 \mathrm{~g} / \mathrm{kg}$ of the combination of benzoic acid and essential oils; $\mathrm{BA}+\mathrm{EO} 4$, negative control $+4 \mathrm{~g} / \mathrm{kg}$ of the combination of benzoic acid and essential oils. GRSP, gross revenue from the sale of piglets (USD); GFC, gross feed cost (USD); OPC, other production costs (USD); NR, net revenue (USD), ROI, return in investment (\%); piglet cost $/ \mathrm{kg}$, cost per kilo of piglet produced (USD); SEM, standard error of the mean. Means followed by different letters are significantly different according to the Turkey test $(p<0.05)$.

There was a significant increase $(p<0.05)$ in gross revenue from piglet sales in the benzoic acid and the $3 \mathrm{~g} / \mathrm{kg}$ benzoic acid and essential oils combination groups compared to the negative control group piglets. There was also a significant increase $(p<0.05)$ in net revenue when the $3 \mathrm{~g} / \mathrm{kg}$ and $4 \mathrm{~g} / \mathrm{kg}$ benzoic acid and additive combination treatments were used compared to the negative control. Return on investment was better $(p<0.05)$ for the benzoic acid and $3 \mathrm{~g} / \mathrm{kg}$ and $4 \mathrm{~g} / \mathrm{kg}$ combination groups compared to the negative control group without differing from the positive control. The cost per kilo of piglet produced was lower $(p<0.05)$ for the $3 \mathrm{~g} / \mathrm{kg}$ and $4 \mathrm{~g} / \mathrm{kg}$ benzoic acid combination groups compared to the negative control group and equal $(p>0.05)$ in comparison with the positive control. The $3 \mathrm{~g} / \mathrm{kg}$ dose has the best cost $/$ benefit ratio. 


\section{Discussion}

The dose of inoculum used in this trial was based on a previous trial by our group [28], however, it was low if compared to other trials [35-37]. Nevertheless, the challenge seemed to be effective at increasing the diarrhea among the piglets as higher values were observed for the first period evaluated. However, to better elucidate its effect, one treatment without the challenge should be provided, and this is thus a limitation of our study. In future trials, a treatment with it should be included to ensure the efficacy of the challenge and the beneficial effects of the additives.

The use of benzoic acid (BA) generally results in benefits in body weight gain, ADFI, and feed conversion of piglets after weaning [19,28,38-40]. These benefits may be related with the fact that BA administration promotes the production and activation of digestive enzymes such as trypsin, lipase, amylase, maltase, sucrose, and lactase. In addition, BA improves the absorption of nutrients [41]. The use of essential oils also favors increased ADFI, greater piglet weight [42,43], and better feed conversion $[44,45]$. Studies show similarly significant results among piglets supplemented with an antibiotic or essential oils in terms of weight gain and feed conversion, highlighting the possibility of substituting antibiotics $[46,47]$.

The better performance at 35 days old resulting from the combination of additives at $3 \mathrm{~g} / \mathrm{kg}$ (BA+EO3) compared to the negative control was not accompanied by greater ADFI. The animals in the $\mathrm{BA}+\mathrm{EO} 3$ group probably presented better gastrointestinal tract conditions and a better rate of nutrient digestibility. As noted by Zhang et al. [48], providing $3 \mathrm{~g} / \mathrm{kg}$ of benzoic acid $+0.1 \mathrm{~g} / \mathrm{kg}$ of essential oils was efficient in increasing apparent total digestibility of dry matter and nitrogen in piglets at twenty-one days of age in the nursery. Essential oils and benzoic acid are regarded as stimulants of digestive enzyme secretion, which may improve nutrient absorption and feed conversion $[26,49,50]$. Moreover, this combination improves the intestinal mucosal barrier integrity in enterotoxigenic challenged pigs [51].

In the present study, the use of the thymol, 2-methoxyphenol, eugenol, piperine, and curcumin components in combination with benzoic acid may have resulted in the greater weight gain for the $\mathrm{BA}+\mathrm{EO} 3$ piglets compared to the negative control group, due to the joint action of the essential oils. In contrast, the inclusion of only one essential oil associated with benzoic acid may not improve weight gain and ADFI in this period compared with the negative control group, as observed by Diao et al. [52]. It is known that the action of the major component of a plant can be potentiated by secondary components, causing a synergistic effect, in the form of blends, unlike when a component is used separately $[46,53,54]$.

Although the combinations of additives at $3 \mathrm{~g} / \mathrm{kg}(\mathrm{BA}+\mathrm{EO} 3)$ and $4 \mathrm{~g} / \mathrm{kg}(\mathrm{BA}+\mathrm{EO} 4)$ positively affected the performance variables in some periods evaluated, the combination at the lower level of $2 \mathrm{~g} / \mathrm{kg}$ (BA+EO2) showed inferior performance. This result may be related to the lower amount of benzoic acid $(1.8 \mathrm{~g} / \mathrm{kg})$ and essential oils $(0.072 \mathrm{~g} / \mathrm{kg})$ lacking a sufficient concentration and synergy to improve the performance variables, thus contrasting with some of the positive results for these variables when these additives are used. In the literature, superior performance characteristics for piglets receiving benzoic acid resulted from a linear effect of the addition at the following levels: 0 , $2.5,5.0$, and $7.5 \mathrm{~g} / \mathrm{kg}$ [55]. In addition, positive effects of essential oils on ADFI and weight gain in piglets can be observed with the inclusions of 0.1 and $0.15 \mathrm{~g} / \mathrm{kg}$ [22], which are greater levels than the $\mathrm{BA}+\mathrm{EO} 2$ group received.

Considering the performance of piglets throughout the nursery phase, benzoic acid and combinations with EO at the levels of $3 \mathrm{~g} / \mathrm{kg}$ and $4 \mathrm{~g} / \mathrm{kg}$ favored a greater final BW in the piglets, similarly to what was observed for the piglets receiving the antibiotic. Their performance was improved, possibly due to better nutrient digestibility, as well as increased bacterial diversity and richness caused by organic acid and the essential oils [53,56-58].

The treatments did not influence the incidence of diarrhea among the piglets, as also observed by Halas et al. [40] and Pu et al. [51] in pigs challenged with enterotoxigenic E. coli and supplemented with benzoic acid. The distribution of diarrhea among the piglets, regardless of the treatment, 
is concentrated in the first week after weaning, as is typical of this period due to the stress and physiological unpreparedness for the food change. It remained high during the second week of the experiment, because on the seventh and eighth day of nursery, the piglets were inoculated with the highly pathogenic bacterial strain of Escherichia coli F4.

Just as the treatments presented no effect on diarrhea, the microbiological profile was also not altered by them. The results differ from studies such as that of Diao et al. [17], in which the use of benzoic acid lowered the Escherichia coli count and raised the count of Bifidobacterium spp. in the ileum of piglets. The plant extracts are able to inhibit this mechanism and can modulate the biofilm formation and the motility of E. coli $[59,60]$. We speculate that in this study, the benzoic acid and essential oils may have been inhibitors of quorum sensing, reducing the communication of bacterial populations and improving the performance of the piglets, without altering the count of these microorganisms.

As volatile fatty acids are the major end products of bacterial metabolism in the large intestine of swine, the effect of organic acids or essential oils on augmenting bacterial counts can increase this production. However, in this study the bacterial count remained the same in all treatments, which may have accounted for the similar VFA concentrations between treatments.

The use of benzoic acid or the combination with EO also did not reduce the $\mathrm{pH}$ of the evaluated gastrointestinal tract segments, supporting the suggestion that the effect of benzoic acid is not necessarily linked to a lower $\mathrm{pH}$ in the segments [61]. Its high dissociation constant $(\mathrm{pKa}=4.21)$ hinders its dissociation and acidification of the medium. A similar result was observed by Halas et al. [40], when piglets supplemented with benzoic acid presented no change in gastric $\mathrm{pH}$.

The experimental treatments also did not alter the cholecystokinin count (CCK) in the duodenum. CCK is released post-prandially in response to saturated fat, long-chain fatty acids, amino acids, and peptides that result from protein digestion. It is able to promote constriction of the pyloric sphincter, slowing gastric emptying, and is the main stimulus for the release of pancreatic enzymes and bile in the small intestine [62]. This hormone can be secreted by the I cells of the duodenum and this occurs more easily in acidic conditions [34,63]. Considering this hormone's susceptibility to $\mathrm{pH}$, the absence of a change in duodenum $\mathrm{pH}$ caused by the treatments may have influenced the absence of a significant difference in the CCK count.

Morphological alterations of the intestine may be a consequence of a natural process in pigs older than three weeks of age, where the epithelium undergoes periodic renewal, with migration of crypt cells to the end of the villi. Morphological and functional differentiations occur in this migration [64] and an accelerated renewal rate may result in villi with immature cells and reduced enzymatic activity [65-67]. Thus, the higher villus height in the jejunum of piglets in the negative control group compared to the group that received the combination of additives at a medium level may be indicative of the presence of "immature" cells coming from the crypt, given that these piglets showed much inferior performance in the period from 21 to 49 days of age, which includes the segment sample collection date.

On the other hand, despite a lower villus height in the jejunum of the BA+EO3 group, nutrients were probably absorbed more efficiently, with less damage to the villi, culminating in better performance. However, none of the treatments resulted in an increase or decrease in cellular proliferation in the jejunal crypts of the piglets, as evaluated by immunohistochemistry.

As changes in the intestine of piglets are constant after weaning, some organs may also be susceptible to changes in their weights. However, the experimental treatments did not influence organ size. This result is similar to that of an evaluation of essential oils in chickens, in which there was no increase in the weight of the pancreas, liver, and small intestine, even though there was a change in ADFI in some periods [68]. According to Rao and McCracken [69], the weight of organs may vary according to the energy content and/or protein content of the diet. This fact may clarify the similarity between the relative weights of the organs presented in this research, because the diets used were isoproteic and isocaloric.

Given the positive results for the performance variables evaluated in this study, it is important to evaluate the economic return that can be obtained by investing in the combined use of benzoic acid and 
essential oils in the nursery phase. The cost varied for feed in each treatment; however, when considering how much feed the pig consumed during the experiment and its respective value, there was no increase in expense between including an antibiotic, benzoic acid, or benzoic acid and essential oil combinations in the baseline diet.

Considering the production costs, which are fixed, for any of the treatments evaluated, the use of benzoic acid or the combinations of this acid and essential oils at $3 \mathrm{~g} / \mathrm{kg}$ and $4 \mathrm{~g} / \mathrm{kg}$ resulted in greater net revenue than with the use of a baseline diet without additives. Hence, the return achieved from the amount invested in the piglets for experimental treatments $\mathrm{BA}, \mathrm{BA}+\mathrm{EO} 3$, and $\mathrm{BA}+\mathrm{EO} 4$ was higher than when the baseline feed without additive was used, aside from being equal in terms of the investment made in piglets that received feed with colistin. The cost per kilo of piglet produced also shows that the $\mathrm{BA}, \mathrm{BA}+\mathrm{EO} 3$, and $\mathrm{BA}+\mathrm{EO} 4$ treatments are more advantageous, given that the values were lower than the cost per kilo of piglet in the treatment with baseline feed and equal to those in the treatment with colistin.

\section{Conclusions}

The use of benzoic acid alone ( $5 \mathrm{~g} / \mathrm{kg}$ ) or combined with essential oils ( $3 \mathrm{~g} / \mathrm{kg}$ and $4 \mathrm{~g} / \mathrm{kg}$ ), as evaluated in this study, improves the performance of piglets in the nursery phase and can be used with the same result as the use of the antibiotic colistin.

Author Contributions: Conceptualization, C.A.P.G., C.C.d.S.M., D.G. and V.d.S.C.; methodology, C.A.P.G., C.C.d.S.M., D.G., R.A.F., M.L.T.d.A. and V.d.S.C.; formal analysis, C.A.P.G.; investigation, L.M.R., T.O.d.A.L.N and C.A.P.G.; resources, C.C.d.S.M., D.G. and V.d.S.C.; data curation, L.M.R., T.O.d.A.L.N. and C.A.P.G.; writing—original draft preparation, L.M.R., C.A.P.G. and V.d.S.C.; writing-review and editing, C.C.d.S.M., D.G., L.K.S.A., C.A.P.G., R.A.F., M.L.T.d.A. and V.d.S.C.; supervision, C.A.P.G. and V.d.S.C.; project administration, C.A.P.G. and V.d.S.C.; funding acquisition, V.d.S.C. All authors have read and agreed to the published version of the manuscript.

Funding: This study was funded by DSM Produtos Nutricionais Brasil SA, AnimalNutri-Ciência e Tecnologia, Universidade Federal de Lavras (Minas Gerais, Brazil), Instituto Nacional de Ciência e Tecnologia (INCT), Fundação de Amparo à Pesquisa de Minas Gerais (FAPEMIG), Conselho Nacional de Desenvolvimento Científico e Tecnológico (CNPq), and Fundação de Amparo à Pesquisa do Estado de São Paulo (FAPESP), grant number 2019/17453-4.

Conflicts of Interest: The authors declare they have no conflict of interest.

\section{References}

1. Moeser, A.J.; Klok, C.V.; Ryan, K.A.; Wooten, J.G.; Little, D.; Cook, V.L.; Blikslager, A.T. Stress signaling pathways activated by weaning mediate intestinal dysfunction in the pig. Am. J. Physiol. Gastrointest. Liver Physiol. 2007, 292, 173-181. [CrossRef] [PubMed]

2. Liu, Y.; Ipharraguerre, I.R.; Pettigrew, J.E. Potential Applications of Knowledge of Gut Chemosensing in Pig Production. J. Anim. Sci. 2013, 91, 1982-1990. [CrossRef] [PubMed]

3. Yang, H.; Xiong, X.; Wang, X.; Tan, B.; Li, T.; Yin, Y. Effects of weaning on intestinal upper villus epithelial cells of piglets. PLoS ONE 2016, 11, e0150216. [CrossRef]

4. Saad, S.M.I. Probióticos e prebióticos: O estado da arte. Rev. Bras. Ciências Farm. 2006, 42, 1-16. [CrossRef]

5. Zlotowski, P.; Driemeier, D.; Barcellos, D.E.S.N.; Emilio, D.; Neves, S. Patogenia das diarréias dos suínos: Modelos e exemplos. Acta Sci. Vet. 2008, 36, s81-s86.

6. Pluske, J.R. Feed- and feed additives-related aspects of gut health and development in weanling pigs. J. Anim. Sci. Biotechnol. 2013, 4, 1-7. [CrossRef]

7. Laxminarayan, R.; Duse, A.; Wattal, C.; Zaidi, A.K.M.; Wertheim, H.F.L.; Sumpradit, N.; Vlieghe, E.; Hara, G.L.; Gould, I.M.; Goossens, H.; et al. Antibiotic resistance-the need for global solutions. Lancet Infect. Dis. 2013, 13, 1057-1098. [CrossRef]

8. Cromwell, G.L. Why and how antibiotics are used in swine production. Anim. Biotechnol. 2002, 13, 7-27. [CrossRef]

9. Rhouma, M.; Beaudry, F.; Letellier, A. Resistance to colistin: What is the fate for this antibiotic in pig production? Int. J. Antimicrob. Agents 2016, 48, 119-126. [CrossRef] 
10. Bialvaei, A.Z.; Samadi Kafil, H. Colistin, mechanisms and prevalence of resistance. Curr. Med. Res. Opin. 2015, 31, 707-721. [CrossRef]

11. Sarkar, S.; Hermes DeSantis, E.R.; Kuper, J. Resurgence of colistin use. Am. J. Health Pharm. 2007, 64, 2462-2466. [CrossRef] [PubMed]

12. Hancock, R.E.W. Peptide antibiotics. Lancet 1997, 349, 418-422. [CrossRef]

13. Kempf, I.; Fleury, M.A.; Drider, D.; Bruneau, M.; Sanders, P.; Chauvin, C.; Madec, J.Y.; Jouy, E. What do we know about resistance to colistin in Enterobacteriaceae in avian and pig production in Europe? Int. J. Antimicrob. Agents 2013, 42, 379-383. [CrossRef] [PubMed]

14. Talebi Bezmin Abadi, A.; Rizvanov, A.A.; Haertlé, T.; Blatt, N.L. World Health Organization Report: Current Crisis of Antibiotic Resistance. Bionanoscience 2019, 9, 778-788. [CrossRef]

15. Liu, Y.Y.; Wang, Y.; Walsh, T.R.; Yi, L.X.; Zhang, R.; Spencer, J.; Doi, Y.; Tian, G.; Dong, B.; Huang, X.; et al. Emergence of plasmid-mediated colistin resistance mechanism MCR-1 in animals and human beings in China: A microbiological and molecular biological study. Lancet Infect. Dis. 2016, 16, 161-168. [CrossRef]

16. Diao, H.; Gao, Z.; Yu, B.; Zheng, P.; He, J.; Yu, J.; Huang, Z.; Chen, D.; Mao, X. Effects of benzoic acid (VevoVitall@) on the performance and jejunal digestive physiology in young pigs. J. Anim. Sci. Biotechnol. 2016, 7, 1-7. [CrossRef]

17. Diao, H.; Zheng, P.; Yu, B.; He, J.; Mao, X.B.; Yu, J.; Chen, D.W. Effects of dietary supplementation with benzoic acid on intestinal morphological structure and microflora in weaned piglets. Livest. Sci. 2014, 167, 249-256. [CrossRef]

18. Perez Alvarado, M.A.; Cervantes Lopez, J.; Brana Varela, D.; Mariscal Landin, G.; Cuaron Ibargueengoytia, J.A. Benzoic acid and a product based on Bacillus species to protect piglet productivity and the environment. Rev. Mex. Ciencias Pecu. 2013, 4, 447-468.

19. Guggenbuhl, P.; Séon, A.; Quintana, A.P.; Nunes, C.S. Effects of dietary supplementation with benzoic acid (VevoVitall@) on the zootechnical performance, the gastrointestinal microflora and the ileal digestibility of the young pig. Livest. Sci. 2007, 108, 218-221. [CrossRef]

20. Zhai, H.; Liu, H.; Wang, S.; Wu, J.; Kluenter, A.M. Potential of essential oils for poultry and pigs. Anim. Nutr. 2018, 4, 179-186. [CrossRef]

21. Liu, Y.; Espinosa, C.D.; Abelilla, J.J.; Casas, G.A.; Lagos, L.V.; Lee, S.A.; Kwon, W.B.; Mathai, J.K.; Navarro, D.M.D.L.; Jaworski, N.W.; et al. Non-antibiotic feed additives in diets for pigs: A review. Anim. Nutr. 2018, 4, 113-125. [CrossRef] [PubMed]

22. Li, P.; Piao, X.; Ru, Y.; Han, X.; Xue, L.; Zhang, H. Effects of adding essential oil to the diet of weaned pigs on performance, nutrient utilization, immune response and intestinal health. Asian-Australas. J. Anim. Sci. 2012, 25, 1617-1626. [CrossRef] [PubMed]

23. Tiihonen, K.; Kettunen, H.; Bento, M.H.L.; Saarinen, M.; Lahtinen, S.; Ouwehand, A.C.; Schulze, H.; Rautonen, N. The effect of feeding essential oils on broiler performance and gut microbiota. Br. Poult. Sci. 2010, 51, 381-392. [CrossRef] [PubMed]

24. Suiryanrayna, M.V.A.N.; Ramana, J.V. A review of the effects of dietary organic acids fed to swine. J. Anim. Sci. Biotechnol. 2015, 6, 1-11. [CrossRef]

25. Juven, B.J.; Kanner, J.; Schved, F.; Weisslowicz, H. Factors that interact with the antibacterial action of thyme essential oil and its active constituents. J. Appl. Bacteriol. 1994, 76, 626-631. [CrossRef]

26. Zhai, H.; Luo, Y.; Ren, W.; Schyns, G.; Guggenbuhl, P. The effects of benzoic acid and essential oils on growth performance, nutrient digestibility, and colonic microbiota in nursery pigs. Anim. Feed Sci. Technol. 2020, 262, 114426. [CrossRef]

27. Vondruskova, H.; Slamova, R.; Trckova, M.; Zraly, Z.; Pavlik, I. Alternatives to antibiotic growth promoters in prevention of diarrhoea in weaned piglets: A review. Vet. Med. (Praha) 2010, 55, 199-224. [CrossRef]

28. Silveira, H.; Amaral, L.G.d.M.; Garbossa, C.A.P.; Rodrigues, L.M.; Silva, C.C.d.; Cantarelli, V.d.S. Benzoic acid in nursery diets increases the performance from weaning to finishing by reducing diarrhoea and improving the intestinal morphology of piglets inoculated with Escherichia coli K88+. J. Anim. Physiol. Anim. Nutr. 2018, 102, 1675-1685. [CrossRef]

29. Sakomura, N.; Rostagno, H.S. Métodos de Pesquisa em Nutrição de MonogáStricos; Funep: Jaboticabal-SP, Brazil, 2016; p. 262. 
30. Xiao, D.; Wang, Y.; Liu, G.; He, J.; Qiu, W.; Hu, X.; Feng, Z.; Ran, M.; Nyachoti, C.M.; Kim, S.W.; et al. Effects of chitosan on intestinal inflammation in weaned pigs challenged by enterotoxigenic Escherichia coli. PLoS ONE 2014, 9, e104192. [CrossRef]

31. Playne, M.J. Determination of ethanol, volatile fatty acids, lactic acid, and succinic acids in fermentation liquids by gas chromatography. J. Sci. Food Agric. 1985, 36, 638-644. [CrossRef]

32. Pluske, J.R.; Thompson, M.J.; Atwood, C.S.; Bird, P.H.; Williams, I.H.; Hartmann, P.E. Maintenance of villus height and crypt depth, and enhancement of disaccharide digestion and monosaccharide absorption, in piglets fed on cows' whole milk after weaning. Br. J. Nutr. 1996, 76, 409-422. [CrossRef] [PubMed]

33. Domeneghini, C.; Di Giancamillo, A.; Savoini, G.; Paratte, R.; Bontempo, V.; Dell'Orto, V. Structural patterns of swine ileal mucosa following L-glutamine and nucleotide administration during the weaning period. An histochemical and histometrical study. Histol. Histopathol. 2004, 19, 49-58. [CrossRef]

34. Wang, Y.; Chandra, R.; Samsa, L.A.; Gooch, B.; Fee, B.E.; Michael Cook, J.; Vigna, S.R.; Grant, A.O.; Liddle, R.A. Amino acids stimulate cholecystokinin release through the Ca2+-sensing receptor. Am. J. Physiol. Gastrointest. Liver Physiol. 2011, 300, 528-537. [CrossRef] [PubMed]

35. Xu, X.; Pan, Y.; Xu, B.; Yan, Y.; Yin, B.; Wang, Y.; Hu, S.; Ma, L. Effects of Cortex Phellodendri extract on post-weaning piglets diarrhoea. Vet. Med. Sci. 2020,1-9. [CrossRef]

36. Ren, C.; Zhou, Q.; Guan, W.; Lin, X.; Wang, Y.; Song, H.; Zhang, Y. Immune response of piglets receiving mixture of formic and propionic acid alone or with either capric acid or bacillus licheniformis after Escherichia coli challenge. BioMed. Res. Int. 2019, 2019. [CrossRef]

37. Kiarie, E.; Bhandari, S.; Scott, M.; Krause, D.O.; Nyachoti, C.M. Growth performance and gastrointestinal microbial ecology responses of piglets receiving Saccharomyces cerevisiae fermentation products after an oral challenge with Escherichia coli (K88)1. J. Anim. Sci. 2011, 89, 1062-1078. [CrossRef]

38. Zhai, H.; Ren, W.; Wang, S.; Wu, J.; Guggenbuhl, P.; Kluenter, A.M. Growth performance of nursery and grower-finisher pigs fed diets supplemented with benzoic acid. Anim. Nutr. 2017, 3, 232-235. [CrossRef]

39. Diao, H.; Zheng, P.; Yu, B.; He, J.; Mao, X.; Yu, J.; Huang, Z.; Dai, L.; Wang, Q.; Chen, D. Effects of benzoic acid on growth performance, serum biochemical parameters, nutrient digestibility and digestive enxymes activities of jejunal digesta in weaner piglets. Chin. J. Anim. Nutr. 2013, 25, 768-777.

40. Halas, D.; Hansen, C.F.; Hampson, D.J.; Mullan, B.P.; Kim, J.C.; Wilson, R.H.; Pluske, J.R. Dietary supplementation with benzoic acid improves apparent ileal digestibility of total nitrogen and increases villous height and caecal microbial diversity in weaner pigs. Anim. Feed Sci. Technol. 2010, 160, 137-147. [CrossRef]

41. Mao, X.; Yang, Q.; Chen, D.; Yu, B.; He, J. Benzoic acid used as food and feed additives can regulate gut functions. BioMed. Res. Int. 2019, 2019. [CrossRef] [PubMed]

42. Zeng, Z.; Xu, X.; Zhang, Q.; Li, P.; Zhao, P.; Li, Q.; Liu, J.; Piao, X. Effects of essential oil supplementation of a low-energy diet on performance, intestinal morphology and microflora, immune properties and antioxidant activities in weaned pigs. Anim. Sci. J. 2015, 86, 279-285. [CrossRef] [PubMed]

43. Li, S.Y.; Ru, Y.J.; Liu, M.; Xu, B.; Péron, A.; Shi, X.G. The effect of essential oils on performance, immunity and gut microbial population in weaner pigs. Livest. Sci. 2012, 145, 119-123. [CrossRef]

44. Ahmed, S.T.; Hossain, M.E.; Kim, G.M.; Hwang, J.A.; Ji, H.; Yang, C.J. Effects of resveratrol and essential oils on growth performance, immunity, digestibility and fecal microbial shedding in challenged piglets. Asian-Australas. J. Anim. Sci. 2013, 26, 683-690. [CrossRef]

45. Trevisi, P.; Merialdi, G.; Mazzoni, M.; Casini, L.; Tittarelli, C.; De Filippi, S.; Minieri, L.; Lalatta-Costerbosa, G.; Bosi, P. Effect of dietary addition of thymol on growth, salivary and gastric function, immune response, and excretion of Salmonella enterica serovar Typhimurium, in weaning pigs challenged with this microbe strain. Ital. J. Anim. Sci. 2007, 6, 374-376. [CrossRef]

46. Xu, Y.T.; Liu, L.; Long, S.F.; Pan, L.; Piao, X.S. Effect of organic acids and essential oils on performance, intestinal health and digestive enzyme activities of weaned pigs. Anim. Feed Sci. Technol. 2018, 235, 110-119. [CrossRef]

47. Pedroso, A.A.; Oetting, L.L.; Utiyama, C.E.; Menten, J.F.M.; Lambais, M.R.; Miyada, V.S. Spacial variability of intestinal bacterial population of swine supplemented with antimicrobial or herbal extracts. Rev. Bras. Zootec. 2005, 34, 1225-1233. [CrossRef] 
48. Zhang, Z.F.; Rolando, A.V.; Kim, I.H. Effects of benzoic acid, essential oils and Enterococcus faecium SF68 on growth performance, nutrient digestibility, blood profiles, faecal microbiota and faecal noxious gas emission in weanling pigs. J. Appl. Anim. Res. 2016, 44, 173-179. [CrossRef]

49. Huang, Y.; Yoo, J.S.; Kim, H.J.; Wang, Y.; Chen, Y.J.; Cho, J.H.; Kim, I.H. Effects of dietary supplementation with blended essential oils on growth performance, nutrient digestibility, blood profiles and fecal characteristics in weanling Pigs. Asian-Australas. J. Anim. Sci. 2010, 23, 607-613. [CrossRef]

50. Cho, J.H.; Chen, Y.J.; Min, B.J.; Kim, H.J.; Kwon, O.S.; Shon, K.S.; Kim, I.H.; Kim, S.J.; Asamer, A. Effects of essential oils supplementation on growth performance, IgG concentration and fecal noxious gas concentration of weaned pigs. Asian-Australas. J. Anim. Sci. 2006, 19, 80-85. [CrossRef]

51. Pu, J.; Chen, D.; Tian, G.; He, J.; Zheng, P.; Mao, X.; Yu, J.; Huang, Z.; Zhu, L.; Luo, J.; et al. Protective Effects of Benzoic Acid, Bacillus Coagulans, and Oregano Oil on Intestinal Injury Caused by Enterotoxigenic Escherichia coli in Weaned Piglets. BioMed. Res. Int. 2018, 2018. [CrossRef] [PubMed]

52. Diao, H.; Zheng, P.; Yu, B.; He, J.; Mao, X.; Yu, J.; Chen, D. Effects of benzoic acid and thymol on growth performance and gut characteristics of weaned piglets. Asian-Australas. J. Anim. Sci. 2015, 28, 827-839. [CrossRef] [PubMed]

53. Long, S.F.; Xu, Y.T.; Pan, L.; Wang, Q.Q.; Wang, C.L.; Wu, J.Y.; Wu, Y.Y.; Han, Y.M.; Yun, C.H.; Piao, X.S. Mixed organic acids as antibiotic substitutes improve performance, serum immunity, intestinal morphology and microbiota for weaned piglets. Anim. Feed Sci. Technol. 2018, 235, 23-32. [CrossRef]

54. Kamel, C. A novel look at a classic approach of plants extracts. Feed Mix 2000, 9, 19-24.

55. Gheler, T.R.; Araújo, L.F.; da Silva, C.C.; Gomes, G.A.; Prata, M.F.; Gomide, C.A. Use of benzoic acid for piglets. Rev. Bras. Zootec. 2009, 38, 2182-2187. [CrossRef]

56. Silva Júnior, C.D.; Martins, C.C.S.; Dias, F.T.F.; Sitanaka, N.Y.; Ferracioli, L.B.; Moraes, J.E.; Pizzolante, C.C.; Budiño, F.E.L.; Pereira, R.; Tizioto, P.; et al. The use of an alternative feed additive, containing benzoic acid, thymol, eugenol, and piperine, improved growth performance, nutrient and energy digestibility, and gut health in weaned piglets. J. Anim. Sci. 2020, 98. [CrossRef]

57. Pu, J.; Chen, D.; Tian, G.; He, J.; Zheng, P.; Mao, X.; Yu, J.; Huang, Z.; Luo, J.; Luo, Y.; et al. Effects of benzoic acid, Bacillus coagulans and oregano oil combined supplementation on growth performance, immune status and intestinal barrier integrity of weaned piglets. Anim. Nutr. 2020, 6, 152-159. [CrossRef]

58. Li, S.; Zheng, J.; Deng, K.; Chen, L.; Zhao, X.L.; Jiang, X.; Fang, Z.; Che, L.; Xu, S.; Feng, B.; et al. Supplementation with organic acids showing different effects on growth performance, gut morphology, and microbiota of weaned pigs fed with highly or less digestible diets. J. Anim. Sci. 2018, 96, 3302-3318. [CrossRef]

59. Williams, P. Quorum sensing, communication and cross-kingdom signalling in the bacterial world. Microbiology 2007, 153, 3923-3938. [CrossRef]

60. Niu, C.; Gilbert, E.S. Colorimetric Method for Identifying Plant Essential Oil Components That Affect Biofilm Formation and Structure. Appl. Environ. Microbiol. 2004, 70, 6951-6956. [CrossRef]

61. Franco, L.D.; Fondevila, M.; Lobera, M.B.; Castrillo, C. Effect of combinations of organic acids in weaned pig diets on microbial species of digestive tract contents and their response on digestibility. J. Anim. Physiol. Anim. Nutr. 2005, 89, 88-93. [CrossRef] [PubMed]

62. Sam, A.H.; Troke, R.C.; Tan, T.M.; Bewick, G.A. The role of the gut/brain axis in modulating food intake. Neuropharmacology 2012, 63, 46-56. [CrossRef] [PubMed]

63. Steinert, R.E.; Geary, N.; Beglinger, C. Secretion of gastrointestinal hormones and eating control. J. Anim. Sci. 2013, 91, 1963-1973. [CrossRef] [PubMed]

64. Yang, C.; Albin, D.M.; Wang, Z.; Stoll, B.; Lackeyram, D.; Swanson, K.C.; Yin, Y.; Tappenden, K.A.; Mine, Y.; Yada, R.Y.; et al. Apical Na+-D-glucose cotransporter 1 (SGLT1) activity and protein abundance are expressed along the jejunal crypt-villus axis in the neonatal pig. Am. J. Physiol. Gastrointest. Liver Physiol. 2011, 300, 60-70. [CrossRef] [PubMed]

65. Millet, S.; Kumar, S.; De Boever, J.; Ducatelle, R.; De Brabander, D. Effect of feed processing on growth performance and gastric mucosa integrity in pigs from weaning until slaughter. Anim. Feed Sci. Technol. 2012, 175, 175-181. [CrossRef]

66. Hu, C.H.; Gu, L.Y.; Luan, Z.S.; Song, J.; Zhu, K. Effects of montmorillonite-zinc oxide hybrid on performance, diarrhea, intestinal permeability and morphology of weanling pigs. Anim. Feed Sci. Technol. 2012, 177, 108-115. [CrossRef] 
67. Pluske, J.R.; Williams, I.H.; Aherne, F.X. Villous height and crypt depth in piglets in response to increases in the intake of cows' milk after weaning. Anim. Sci. 1996, 62, 145-158. [CrossRef]

68. Çabuk, M.; Bozkurt, M.; Alçiçek, A.; Akbap, Y.; Küçükyýlmaz, K. Effect of a herbal essential oil mixture on growth and internal organ weight of broilers from young and old breeder flocks. S. Afr. J. Anim. Sci. 2006, 36, 135-141. [CrossRef]

69. Rao, D.S.; McCracken, K.J. Energy: Protein interactions in growing boars of high genetic potential for lean growth. 1. Effects on growth, carcass characteristics and organ weights. Anim. Sci. 1992, 54, 75-82. [CrossRef]

Publisher's Note: MDPI stays neutral with regard to jurisdictional claims in published maps and institutional affiliations.

(C) 2020 by the authors. Licensee MDPI, Basel, Switzerland. This article is an open access article distributed under the terms and conditions of the Creative Commons Attribution (CC BY) license (http://creativecommons.org/licenses/by/4.0/). 